\title{
Covid-19: Trump sought to buy vaccine developer exclusively for US, say German officials
}

\author{
Owen Dyer
}

Montreal

The US president, Donald Trump, made secret overtures to the German company CureVac-one of the leading contenders to create a covid-19 vaccine-in the hope of luring it to the United States, say senior officials in the German government.

Germany's Welt am Sonntag newspaper reported that the offer, valued at about $\$ 1$ bn $(£ 829 \mathrm{~m} ; € 912 \mathrm{~m})$, stipulated that any vaccine the company developed would be "only for the USA." The company has often said that its products would be offered to all countries.

Senior German officials confirmed the reports and criticised the US government's actions. Horst Seehofer, interior minister, when asked to confirm the newspaper's report, said that he had "heard from several other members of government today that is the case."

Heiko Maas, foreign minister, told the German publisher Funke Mediengruppe, "German researchers are taking a leading role in developing medicines and vaccines as part of a global collaboration. We cannot allow a situation where others want to exclusively acquire the results of their research."

\section{“Extremely unfriendly act”}

Jens Spahn, health minister, assured Germans that the proposal was now "off the table" and that CureVac would develop vaccines "for the whole world, not for individual countries."

In the Bundestag, politicians from all major parties condemned the attempt. "International cooperation is important now, not national self-interest," said Erwin Rüddel, a lawmaker in Angela Merkel's conservative Christian Democratic Union party.

Christian Lindner, leader of the liberal Free Democratic Party, said, "Obviously, Trump will use any means available in an election campaign."

No country should have exclusive access to a vaccine, said Karl Lauterbach of the Social Democratic Party, adding, "The American government has committed an extremely unfriendly act."

Anonymous White House officials told the Washington Post that they knew nothing of the bid, but they added that the president often had private conversations of which they were unaware. An unnamed US official told Agence France-Presse that the report was being "wildly overplayed."

\section{"Not for sale"}

CureVac's American CEO, Daniel Menichella, was among vaccine company leaders who met with Trump at the White House last month. ${ }^{2}$ Menichella was suddenly replaced as the head of the company last week by Ingmar Hoerr. No public explanation was offered.

In a statement CureVac said that it would "abstain from commenting on speculations" and that it rejected "any claims of a possible sale of the company or its technology."

The company's biggest investor, Dietmar Hopp, commented, "We want to develop a vaccine for the whole world and not individual countries."

Germany's economy minister, Peter Altmaier, told the broadcaster $A R D$ that the company had made a "fantastic decision," adding, "Germany is not for sale."

On 16 March, the day after the story went public, the EU announced an $€ 80 \mathrm{~m}$ ( $£ 73 \mathrm{~m} ; \$ 87.8 \mathrm{~m}$ ) support package to help CureVac "scale up development and production of a vaccine against the coronavirus in Europe."

The European Commission president, Ursula von der Leyen, said, "I am proud that we have leading companies like CureVac in the EU. Their home is here, but their vaccines will benefit everyone, in Europe and beyond."

1 Dams J. Donald Trump greift nach deutscher Impfstoff-Firma [Donald Trump reaches for German vaccine company]. Welt am Sonntag 2020 Mar 15. https:/www.welt.de/wirtschaft article206555143/Corona-USA-will-Zugriff-auf-deutsche-Impfstoff-Firma.html. (In German, translatable to English.)

2 Dyer $\mathrm{O}$. Trump claims public health warnings on covid-19 are a conspiracy against him. BMJ 2020;368:m941. 10.1136/bmj.m941 32144176

Published by the BMJ Publishing Group Limited. For permission to use (where not already granted under a licence) please go to http://group.bmj.com/group/rights-licensing/ permissions 